\section{The Vulnerability of Underground Water Resources to Bacteriological Indicators in Parts of Owerri West of Southeastern Nigeria}

\section{Ubuoh Emmanuel Attah}

Department of Environmental Management and Toxicology (EMT), College of Natural Resources and Environmental Management (CNREM), Michael Okpara University of Agriculture, Umudike (MOUAU), P.M.B.7267, Abia State, Nigeria

${ }^{*}$ Corresponding author: Ubuoh Emmanuel Attah, Department of Environmental Management and Toxicology (EMT), College of Natural Resources and Environmental Management (CNREM), Michael Okpara University of Agriculture, Umudike (MOUAU), P.M.B.7267, Abia State, Nigeria, Tel: 08037639777; E-mail: ubuohemmanuel@yahoo.com

Received: September 20, 2017; Accepted: September 28, 2017; Published: September 29, 2017

Copyright: (c) 2017 Attah UE. This is an open-access article distributed under the terms of the Creative Commons Attribution License, which permits unrestricted use, distribution, and reproduction in any medium, provided the original author and source are credited.

\begin{abstract}
The Vulnerability of the selected boreholes to bacteriological indicators in Parts of Owerri West of Southeastern Nigeria was determined using Vulnerability Index (VI). Distances between the selected boreholes and anthropogenic activities were measured. Sampled Borehole (SBH) 3, 5, 8 did not meet the $30 \mathrm{~m}$ WHO STD, while defecation, bathing and washing of clothes were found within the circumference of SBH 6, 9 and 10 respectively. Total bacteria, total coliform and faecal counts were evaluated using the standard plate count method and the Most Probable Number (MPN) technique, respectively. The mean total bacteria count of the selected bore water samples ranged from $0.08-2.73 \times 10^{2} \mathrm{CFU}$ that constituted between $0.59-20.31 \%$, with the mean value of $1.34 \times 10^{2} \mathrm{CFU} / \mathrm{ml}$, Total coliform count ranged from 6-19 MPN/100 ml constituting 4.72-14.96\%, with the mean value of $12.7 \mathrm{MPN} / 100 \mathrm{ml}$ and Faecal coliform count ranged from 9-21 CFU/ml constituting $7.09-14.69 \%$ with the mean value of 14.3 (CFU/100 $\mathrm{ml}$ ) all above the WHO STD respectively [1]. The isolated and identified bacteria include: Enterobacter $s p$., Alcaligenes sp., Escherichia coli, Proteus sp., Klebsiella sp., Pseudomonas aeruginosa, Acinetobacter sp., Staphylococcus aureus and Bacillus $s p$. accordingly. From the result of Vulnerability Index (VI) calculated and rated, the selected boreholes are highly affected by faecal count rated 0.21 within the rating of 0 signifying highly vulnerable. Furthermore, results of total bacteria a, total coliform and overall result of bacteriology using VI rating recorded 1.98, 1.02, 1.07 respectively, indicating highly resilient in rating. The vulnerability of the selected boreholes to bacteria means that, water resources in this area is not suitable for human consumption, hence water borne diseases.
\end{abstract}

Keywords: Vulnerability index; Water resources bacteria; Indicator; Borehole water quality

\section{Introduction}

Community water supplies are recognized internationally as an issue critical to public health [2]. The operation and management of small water supplies may be inadequate due to the limited resources and lack of awareness of factors affecting water quality. The principal public health concern is the use of vulnerable groundwater aquifers without water purification or disinfection measures for drinking purposes. At vulnerable drinking water supplies, the deficiencies in multi-barrier approach increase the risk of drinking water contamination [3].

In many developing countries, availability of water has become a critical and urgent problem and it is a matter of great concern to families and communities depending on non-public water supply system [4]. Increase in human population has exerted an enormous pressure on the provision of safe drinking water especially in developing countries [5]. Unsafe water is a global public health threat, placing persons at risk for a host of diarrheal and other diseases as well as chemical intoxication [6]. Unsanitary water particularly has devastating effects on young children in the developing world. Each year, more than 2 million persons, mostly children less than 5 years of age, die of diarrheal disease [7].
The potential of drinking water to transport microbial pathogens to great numbers of people, causing subsequent illness is well documented in different countries [8]. A total number of 1.2 million water related cases of illness has been reported by Hunter and Syed [9], while Pruss et al. [10] estimated that water, sanitation and hygiene were responsible for $4.0 \%$ of all deaths and $5.7 \%$ of the total disease burden occurring worldwide. According to Tuku and Akobundu, poor sanitation and lack of save water makes communities vulnerable to diseases such as shigellosis, amoebiosis, schistosomiasis, typhoid, leptospirosis, infectious hepatitis, giardiasis and paratyphoid. This further confirms the fact that the supply of clean and treated water remains a challenge in developing countries especially in the rural areas.

Nearly $90 \%$ of diarrheal-related deaths have been attributed to unsafe or inadequate water supplies and sanitation conditions affecting a large part of the world's population [6]. An estimated 1.1 billion persons (one sixth of the world's population) lack access to clean water and 2.6 billion to adequate sanitation [6]. A collaborative, interdisciplinary effort to ensure global access to safe water, basic sanitation, and improved hygiene is the foundation for ending cycle of poverty and diseases [6]. The World Health Organization (WHO) estimates that about 1.1 billion people globally drink unsafe water [11], and the vast majority of diarrheal disease in the world [88\%] is attributable to unsafe water, sanitation and hygiene. According to Obire et al. [12], poor water quality, sanitation and hygiene accounts for 1.7 million deaths a year worldwide (3.1\% of annual deaths). 
In Nigeria, only $60 \%$ of households have access to improved sources of drinking water, a situation that affects both the rich and the poor and even those who rely on deep bore wells cannot reliably secure uncontaminated water [13], and pollution of groundwater stems from different sources [14]. These include insanitary condition during borehole construction, splashing of runoff into wells, if left uncovered, flooding at borehole site, leachate from old buried waste pit or latrine into the hole through cracks in aquifer and annular of the hole, closeness of boreholes to septic tanks especially where space is a constraint and as such boreholes are drilled at times at old garbage landfill site formations through which the wastewater is retrieved from the holes [15].

The use of certain bacteria as indicators of potential presence of pathogenic micro-organisms in water is the standard means of assessing the microbiological quality of a water body [16]. Groundwater is perceived as being intently of pristine quality [17], and many of the rural areas in Nigeria are supplied with groundwater for domestic use without treatment [18]. In Nigeria, many of the rural populace do not have access to adequate water and therefore, depend on other alternatives like wells and surface water sources for domestic use [8]. In villages in developing countries, many boreholes are located closer to septic tanks and latrine against the WHO recommended $30 \mathrm{~m}$ away from latrine and $17 \mathrm{~m}$ septic tanks [19], against the background, water resources will be vulnerable.

Vulnerability assessment is an approach used to describe the potential for harm from a diverse range of hazards at local, regional, national or global scales [20]. A range of biophysical, social, economic, or cultural factors may be used as indicators of vulnerability [21]. Water-associated diseases account for approximately $10 \%$ of the global disease burden, representing a significant source of morbidity and mortality worldwide [22]. These infections are spread by waterborne agents (e.g., E. coli O157:H7, Vibrio cholera O139), vectors carrying viruses and parasites (e.g., dengue, malaria), and water contact (e.g., schistosomiasis). Hence, an integrated control approaches are critical to addressing water associated diseases impacted by a range of environmental and social factors, and there is a growing need for tools to assess vulnerability at the water-health nexus.

Against this background, therefore there need to conduct microbial analysis of groundwater resources in the study area, since according to Water Act (1998), the quality of groundwater anthropogenic impacts on water resources can be identified and remediated and so can the water resources can be protected against deterioration through pollution.

\section{Materials and Methods}

\section{Study area}

Owerri West Local Government Area with its headquarters at Uumuguma is located between latitudes of $5023^{\prime}$ and $5034 \mathrm{~W}$ and between longitudes of $6050^{\prime}$ and $70 \mathrm{E}$, and has 15 autonomous communities namely Obinze, Avu, Nekede, Ihiagwa, Amakohia Ubi, Ndegwu, Okuku, Eziobodo, Oforola, Ohi, Umuguwaand Orogwe, Okolachi, Emeabiam and Irete. Oforola as a study location lies within Latitude $5041^{\prime} \mathrm{N}$ and $6031^{\prime} \mathrm{E}$ and Longitude $7034^{\prime} \mathrm{N}$ and $6015^{\prime} \mathrm{E}$ [23]. The climate falls within the humid tropical climates. The rainfall distribution pattern is bi-modal with peaks in July and September. There is normally a short period of low precipitation between end of July and early August usually termed "August break". The rainfall pattern gives rise to two distinct growing seasons, the early season (April to July) and the late season (mid-August to mid-October or November). There are four to five months of dry season part of which is characterized by cool dry northeastern wind called harmattan. The major occupation of the people is farming, from where they generate income to support livelihood.

\section{Random selection of the boreholes water sampling location}

For water sampling locations, the following communities were randomly chosen for the study with SBH1-10 indicating sampled boreholes in Oforola: 1-Umuimika, 2- Amaku, 3- Oboagwa, 4Umuogidi, 5- Umuadi, 6- Umagubiam, 7- Amogi, 8- Umuezuroche, 9Umuchi and 10- Umeke.

\section{Sampling borehole water technique in the study locations}

Collection of Water Samples Ten water samples were collected from ten boreholes randomly selected according to personal observation and anthropogenic activities within and around the selected boreholes. The samples' locations were designated SBH signifying sampled bore holes from Oforola village, using standard methods as described by APHA [24] for water sampling. Each sample for analysis was collected using a clean two liter plastic container with a screw cap which was thoroughly washed with detergent, soaked with acid and rinsed with distilled water. At the point of collection, the container was rinse three times with the water sample. All the samples were stored in laboratory, freshly refrigerated at $4^{\circ} \mathrm{C}$ in a cooler packed with, ice blocks prior to analysis to avoid microbial action affecting their concentration.

\section{Analysis of sampled borehole water for bacteriological indicators}

Total bacterial count: The total bacterial count was determined by pour plate technique using standard methods [24]. Nutrient agar medium was used for the enumeration of bacteria in the samples.

Total coliform count: This was determined by MPN index method using 3-3-3 regimen. MacConkey broth was used and positive result was indicated by acid and gas production on incubation at $37^{\circ} \mathrm{C}$ for 48 hours.

Faecal coliform count: Faecal coliform count was determined using Eosin Methylene Blue medium using pour plate technique. Organisms with greenish metallic sheen were taken as positive for $E$. coli. This was further confirmed by the ability of the organism to ferment lactose at $44.5^{\circ} \mathrm{C}$.

\section{Vulnerability Index (VI)}

Vulnerability is described as the condition of a system, or a propensity to be adversely affected [25]. It encompasses exposure to harmful environmental or social stresses, susceptibility to these stresses, and the capacity to cope or adapt [26], often within the context of a particular hazard [27]. The Vulnerability Index was calculated by summing the indicator scores [28]. The index was calculated based on water-associated diseases account for approximately $10 \%$ of the global disease burden, representing a significant source of morbidity and mortality worldwide [22].

This indicator is calculated as:

$\mathrm{VI}=\mathrm{Q}_{\max }-\mathrm{Q}_{\min } /$ Mean Equation 1. 
Citation: Attah UE (2017) The Vulnerability of Underground Water Resources to Bacteriological Indicators in Parts of Owerri West of Southeastern Nigeria. J Environ Anal Chem 4: 215. doi:10.4172/2380-2391.1000215

Page 3 of 7

Where, $\mathbf{Q}_{\max }-$ Highest value of indicator in the set; $\mathbf{Q}_{\min }-$ Lowest value of an indicator in the set; Mean= Summation of $\mathrm{Q}$ divided by $\mathrm{Qn}$

Or

Susceptibility component:

$\mathrm{X} \sim(\mathrm{x}\{\mathrm{xmin})=(\mathrm{xmax}\{\min )$ Equation 2.
A weighting of exposure and susceptibility indicators to construct the final index was based on contribution to overall vulnerability. Weightings of exposure and susceptibility indicators were tested to determine the optimal contribution of each to water borne diseases in the study area with rating $0-1$ and Vulnerability-resilience description: 0 Highly vulnerable, 0.25 Moderately vulnerable, 0.50 Threshold, 0.75 Moderately resilient and 1.00 Highly resilient.

\begin{tabular}{|c|c|c|c|c|c|}
\hline S. No. & $\begin{array}{l}\text { Sampled } \\
\text { (Manpower) }\end{array}$ & Borehole $\quad(\mathrm{SBH})$ & Code & Distance $(m)$ & Sampling Area Descriptions \\
\hline 1 & SBH & & 1 & 34.6 & Pit latrine \\
\hline 2 & SBH & & 2 & 35.3 & Pit latrine \\
\hline 3 & SBH & & 3 & 23.9 & Pit latrine \\
\hline 4 & SBH & & 4 & 45.8 & Septic tank \\
\hline 5 & SBH & & 5 & 18.9 & Pit latrine \\
\hline 6 & SBH & & 6 & 21.4 & Open space for washing of clothes, defecation etc. \\
\hline 7 & SBH & & 7 & 37.2 & Degradable waste dump \\
\hline 8 & SBH & & 8 & 32 & Pit latrine \\
\hline 9 & SBH & & 9 & 24.6 & Open space for washing \\
\hline 10 & SBH & & 10 & 28.3 & Septic tank \\
\hline
\end{tabular}

Table 1: Distance from closest potential sources of contamination (meters).

From Table 1, the measurement taken from ten sampled boreholes in the study area indicated that SBH 1,2 and 8 ranged between $34.6-35.3 \mathrm{~m}$ from pit latrine above the $30 \mathrm{~m}$ stipulated by WHO, while SBH 3, $5(23.9 \mathrm{~m}, 18.9 \mathrm{~m})$ and are below the $30 \mathrm{~m}$ for pit latrine location with borehole [19]. For septic tanks, SBH 4 and 10 (45.8, 24.6 $\mathrm{m})$ locations met the $17 \mathrm{~m}$ WHO standard expected of the septic tank sitting. SBH 6 and 9 were located within 21.4 and $24.6 \mathrm{~m}$ below $30 \mathrm{~m}$ WHO STD where inhabitants were found washing clothes, cars, bathing of children and other household belongings within the radius of the selected boreholes. Degradable wastes were also found within SBH 7 within $37.2 \mathrm{~m}$. The result further indicated that SBH 5-6 were the closest to the pit latrine and open space where clothes, cars, bathing and animals like goats, sheep etc. were done (Figure 1).

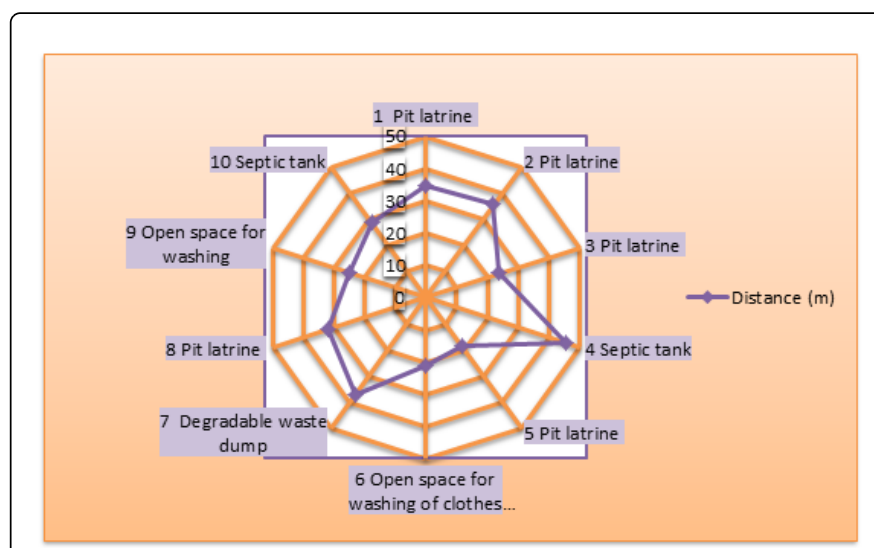

Figure 1: Web showing distance boreholes land uses in the study area.

\begin{tabular}{|l|l|l|l|l|l|l|}
\hline Sample & $\begin{array}{l}\text { Total Bacterial Count (TBC) (CFU/ } \\
\mathbf{1 0 0} \mathbf{m l}) \mathbf{\times} \times \mathbf{1 0}^{\mathbf{2}}\end{array}$ & $\begin{array}{l}\text { Total Coliform Count } \\
\text { (TC) (MPN/100 } \mathbf{m l})\end{array}$ & $\%$ & $\begin{array}{l}\text { Faecal coliform count } \\
\text { (CFU/100 } \mathbf{m l})\end{array}$ \\
\hline SBH1 & 1.23 & 9.15 & 12 & 9.45 & 17 & 17.89 \\
\hline SBH2 & 1.95 & 14.51 & 19 & 14.96 & 15 & 10.49 \\
\hline SBH3 & 0.7 & 5.27 & 8 & 6.3 & 11 & 7.69 \\
\hline SBH4 & 1.41 & 10.49 & 14 & 11.02 & 9 & 6.29 \\
\hline
\end{tabular}


Citation: Attah UE (2017) The Vulnerability of Underground Water Resources to Bacteriological Indicators in Parts of Owerri West of Southeastern Nigeria. J Environ Anal Chem 4: 215. doi:10.4172/2380-2391.1000215

Page 4 of 7

\begin{tabular}{|c|c|c|c|c|c|c|}
\hline SBH5 & 1.41 & 10.49 & 16 & 12.6 & 18 & 12.59 \\
\hline SBH6 & 1.06 & 7.89 & 9 & 7.09 & 12 & 8.39 \\
\hline SBH7 & 2.73 & 20.31 & 19 & 14.96 & 21 & 14.69 \\
\hline SBH8 & 1.65 & 12.28 & 13 & 10.24 & 16 & 11.19 \\
\hline SBH9 & 0.08 & 0.59 & 6 & 4.72 & 14 & 9.79 \\
\hline SBH10 & 1.22 & 9.08 & 11 & 8.66 & 10 & 6.99 \\
\hline Total & 13.44 & 100 & 127 & 100 & 143 & 100 \\
\hline Mean & 1.34 & - & 12.7 & - & 14.3 & - \\
\hline WHO STD (1996) & $0<1$ & & 0 & & 0 & \\
\hline
\end{tabular}

Table 2: Bacteriological indicators of sampled water from the selected boreholes and comparison with the WHO minimum standards for drinking water.

From Table 2, the result of Total Bacterial Count (TBC) in sampled boreholes ranged $0.08-2.73 \mathrm{CFU} \times 10^{2}$ that constituted between $0.59-20.31 \%$, with the mean value of $1.34(\mathrm{CFU} / 100 \mathrm{ml}) \times 10^{2}$. This result is above the $0<1$ WHO STD (1996) for drinking water. Total coliform count ranged from 6-19 MPN/100 ml constituting
4.72-14.96\%, with the mean value of $12.7 \mathrm{MPN} / 100 \mathrm{ml}$, while Faecal coliform count ranged from 9-21 CFU/ml constituting 7.09-14.69\% with the mean value of $14.3(\mathrm{CFU} / 100 \mathrm{ml})$ all above the $0(\mathrm{MPN} / 100$ $\mathrm{ml}),(\mathrm{CFU} / 100 \mathrm{ml})$ WHO STD (1996) respectively.

\begin{tabular}{|c|c|c|c|c|c|c|c|c|c|c|c|c|}
\hline Bacterial Isolates & Frequency $^{\mathrm{a}}$ & $(\%)^{b}$ & SBH1 & SBH2 & SBH3 & SBH4 & SBH5 & SBH6 & SBH7 & SBH8 & SBH9 & SBH10 \\
\hline Enterobacter sp. & 4 & 16.7 & + & - & - & - & + & - & - & + & - & + \\
\hline Alcaligenes $s p$ & 3 & 12.5 & - & + & & + & - & + & - & - & - & - \\
\hline E. coli & 5 & 20.8 & + & & + & & + & + & - & - & + & + \\
\hline Proteus sp. & 1 & 4.16 & - & - & - & - & - & - & + & - & - & - \\
\hline Klebsiella sp. & 2 & 8.3 & - & + & - & - & - & - & + & - & - & - \\
\hline Pseudomonas A. & 2 & 8.3 & - & - & + & - & + & - & - & - & - & - \\
\hline Acinetobacter sp. & 2 & 8.3 & + & - & - & - & - & - & - & - & - & + \\
\hline Staphylococcus A. & 3 & 12.5 & - & - & - & + & - & + & - & - & + & - \\
\hline Bacillus sp. & 2 & 8.3 & - & - & - & - & + & - & - & + & - & - \\
\hline Total & & 100 & 3 & 2 & 2 & 2 & 4 & 3 & 2 & 2 & 2 & 3 \\
\hline
\end{tabular}

Table 3: Distribution of bacterial isolates from the selected borehole waters: $\mathrm{SBH}=$ Sampled borehole; $+=$ Positive; $-=$ Absent; a=frequency of occurrence of total isolates from each sampled borehole; $b=\%$ relative frequency of occurrence of individual isolates across the sampled borehole.

Table 3 shows the occurrence and frequency of isolated bacterial species in the selected borehole Water Samples in the area. The result showed that ten [10] different bacteria were isolated from sampled water from the selected boreholes, with $E$. coli as the dominant bacteria having a frequency occurrence of $20.8 \%$ which is the highest percentage that is suspected to be due to unsanitary environment where the water sample locations were sited near houses, pit latrines, septic tanks, bathing and other unwholesome activities. The other bacteria isolated and percentage of their occurrences were Enterobacter sp. with $16.7 \%$, Alcaligenes $s p$. with $12.5 \%$, Proteus $s p$. recorded 4.16\%, Klebsiella sp., Pseudomonas aeruginosa, Acinetobacter sp., Bacillus sp. constituting $8.3 \%$ respectively and Staphylococcus aureus being $12.5 \%$. From the result, it is further observed that sampled water from SBH 5 recorded the highest sum of bacteria species isolated to include Enterobacter sp., E. coli, Pseudomonas aeruginosa and Bacillus $s p$. attributed to the nearness of borehole to the pit latrine in Umuadi community with distance of 18.9 $\mathrm{m}$ against $30 \mathrm{~m}$ WHO standard. The second boreholes with three genera of the same species are SBH1 and 10 having Enterobacter sp., E. coli and Acinetobacter sp. each and SBH6 recording Alcaligenes sp., E. coli and Staphylococcus aureus, with other boreholes having two genera each.

\begin{tabular}{|l|l|l|l|l|l|}
\hline $\begin{array}{l}\text { Ratin } \\
\mathbf{g}\end{array}$ & TB & TC & FC & TB,TC,FC/ $\mathbf{n}$ & $\begin{array}{l}\text { Vulnerability-resilience } \\
\text { description }\end{array}$ \\
\hline 0 & & & 0.21 & & Highly vulnerable \\
\hline
\end{tabular}




\begin{tabular}{|l|l|l|l|l|l|}
\hline 0.25 & & & & & Moderately vulnerable \\
\hline 0.5 & & & & & Threshold \\
\hline 0.75 & & & & & Moderately resilient \\
\hline$>1.00$ & 1.98 & 1.02 & & 1.07 & Highly resilient \\
\hline
\end{tabular}

Table 4: Assessing vulnerability of water resources to water-associated disease in Oforola: TB=Total Bacteria Count; TC=Total Coliform; $\mathrm{FC}=$ Faecal Count.

Highly vulnerable is defined as hand pumped wells that are of significant risk due to inadequate care, protection or access to essential services like operation maintenance culture [29]. From Table 4, vulnerability index calculated and rated indicated that the selected boreholes (hand pump) are highly affected by faecal count rated 0.21 within the rating of 0 signifying highly venerable. Furthermore, results of TB, TC and overall result of bacteriology using VI rating recorded $1.98,1.02$ and 1.07 respectively, indicating highly resilient in rating.

\section{Results and Discussion}

From result the measurement taken from ten sampled boreholes in the study area indicated that some pit latrines and septic tanks did not comply with WHO STD and villagers were found washing clothes, cars, bathing of children and other household belongings within the radius of the selected boreholes. Above all, animals and defecation were also found around boreholes selected. These findings agree with the reports of Idika et al. [30] that wells in Burkina Faso were contaminated by seepage of a pool of water around well-head and that the pool was contaminated by pig faeces. It has been shown that location of wells too close to pit latrines, septic tanks or refuse dumps could pollute ground water [31].

The results of Total Bacterial Count (TBC), Total coliform count and faecal coliform count from the selected boreholes were above the WHO STD respectively [1]. This result is against the observation that, no sampled water should contain Faecal Coliform or E. coli, and ideally there should be no Total Coliform [32]. Findings of faecal contamination of groundwater have been reported by Boyer and Neel [33], in rural areas, central Finland are where cattle breeding areas with intensive farming producing large amounts of faecal material. It is also possible that human excreta may leach into groundwater since there are rural areas having tap water, but being in lack of sewerage networks. Thus, private septic tanks, pit latrine, etc. may cause sewage penetration into groundwater sources in rural areas [34]. This is the situation in this study (Table 1).

The occurrence and frequency of isolated bacterial species in the selected borehole Water Samples in the area showed E. coli as the dominant bacteria suspected to be due to unsanitary environment where the water sample locations were sited near houses, pit latrines, septic tanks, bathing and other unwholesome activities. The other bacteria isolated included Enterobacter sp., Alcaligenes sp., Proteus sp., Klebsiella sp., Pseudomonas aeuginosa, Acinetobacter sp., Bacillus sp. and Staphylococcus aureus due to the closeness to human activities. However, in a related study on microbial pollution of ground water in Owerri, Imo State, it was established that the bacterial content exceeded the maximum permissible limit allowed for drinking water [35], due to Indiscriminate and unregulated pig husbandry pose serious health hazards to inhabitants of rural communities [31].
Accordingly, faecal contamination has also been identified as a major problem encountered in small groundwater supplies even though systematic information on the extent of waterborne infections is lacking [36]. From the result, vulnerability index of the selected boreholes are highly affected by faecal count rated as highly venerable. The high faecal coliform in most of the water sources studied is indicative of possible pollution by human excreta. This agrees with reports by Duru et al. [37] and Okechi et al. [38]. Furthermore, results of TB, TC indicated highly resilient in rating respectively. This shows that with proper and adequate maintenance culture and attitudinal change water resources in the area can bounce back to microbial- free water. Resilience relates to performance during the design life but addresses performance during periods in which the required level of service is not met (i.e., when subject to threats). Resilience-based design aims to overcome failure and ensure that the system is safe to fail [39]. Faecal pollution of water may be derived from sewage effluents, defecation and/or shedding, livestock (cattle, sheep, etc.), industrial processes, farming activities, domestic animals (such as dogs) and wildlife [40]. These sources can include pathogenic organisms that cause gastrointestinal infections following ingestion or infections of the upper respiratory tract, ears, eyes, nasal cavity and skin [41].

The United Nations also recognizes that improved water management is critical to ensuring sustainable development and has recommended building long-term resilience through stronger institutions and investment in infrastructure [42]. However, the goal of sustainable urban water management seems as far away as ever [43]. Several resilience frameworks do exist in the literature [44], but lack the community participation, awareness and institutional support.

\section{Conclusion}

On the basis of the siting of water resources like boreholes in the study area, standards in terms of locational analysis was not met leading to their closeness to human activities that degraded water quality in which the water supply sources are not suitable for domestic uses and drinking due to the prevalence of bacteria. Also, pit latrines, septic tanks are rampant, dug anywhere not considering geology and soil types. Furthermore, there is indiscriminate and deliberate littering of animal wastes, domestic solid wastes around water sources, However, Total Bacteria count, Total coliform and faecal count recorded in the sampled borehole water were above the WHO permissible limits, and raised serious health challenges within the community, Oforola. The presence of the bacteria isolate in all the sampled boreholes imply that consumers of such waters are vulnerable to the risk of infection, hence VI showing highly vulnerable, and highly resilience of boreholes in the area. Since water quality in the area is doubtful, treatment is recommended to remove or destroy pathogens. This can be accomplished through filtration with native leaves [45], boiling, white transparent clothes [29], and the use of chemical additives like alum and chlorine thereby minimizing the risk of water borne diseases. Proper sanitation and hygiene must be ensured by the villagers in order to avoid microbes entering to underground water systems.

\section{References}

1. WHO (1996) Guidelines for Drinking Water Quality. Health Criteria and other Supporting Information. 2nd Edition, WHO, Geneva pp. 271. 
2. Hulsmann A (2005) Small systems large problems- A European inventory of small water systems and associated problems. WeKnow (Web-based European Knowledge Network on Water)/Endware Report, 1 June 2005.

3. Joerin F, Cool G, Rodriguez MJ, Gignac M, Bouchard C (2010) Using multi-criteria decision analysis to assess the vulnerability of drinking water utilities. Environmental Monitoring and Assessment 166: 313-330.

4. Okonko IO, Adejoye OD, Ogunnusi TA, Fajobi EA, Shittu OB (2008) Microbiological and physiochemical analysis of different water samples used for domestic purposes in Abeokuta and Ojota, Lagos State, Nigeria. Afr J Biotechnol 7: 617-621.

5. Umeh CN, Okorie OI, Emesiani GA (2005) Towards the provision of safe drinking water: The bacteriological quality and safety of sachet water in Awka, Anambra State. In: the Book of Abstract of the 29th Annual Conference \& General Meeting on Microbes As Agents of Sustainable Development, organized by Nigerian Society for Microbiology (NSM), University of Agriculture, Abeokuta, pp. 22.

6. Hughes JM, Koplan JP (2005) Saving lives through global safe water. J Emerg Infect Dis 11: 1636-1637.

7. Parashar U, Bresee JS, Glass RI (2003) The global burden of diarrhoeal disease in children. Bull World Health Organ 81: 236.

8. Ibeneme SI, Ofulume AB, Okechi RN, Haruna IV, Ukiwe LN, et al. (2014) Assessment of the Quality of Water Resources of Ahaba and Ovim Areas, Isuikwuato Southeastern Nigeria. Int J Curr Microbiol App Sci 3: 181-193.

9. Hunter PR, Syed Q (2001) Community surveys of self-reported diarrhea can dramatically overestimate in size of outbreaks of waterborne cryptosporidiosis. Water Sci Technol 43: 27-30.

10. Prüss A, Kay D, Fewtrell L, Bartram J (2002) Estimating the burden of disease from water, sanitation, and hygiene at a global level. Environmental Health Perspectives 110: 537-542.

11. Hunter PR, Waite M, Ronchi E (2002) Drinking Water and Infectious Disease: Establishing the Links. London: IWA Publishing pp. 13.

12. Obire O, Tamuno DC, Wemedo SA (2005) Bacteriological Water Quality of Elechi Creek in Port Harcout, Nigeria. J Appl Sci Environ Manag 9: 7984.

13. Okorie PU, Acholonu ADW (2008) Water quality studies of Nworie River in Owerri, Nigeria. J Mississippi Acad Scien 53: 232-238.

14. Onwughara NI, Ajiwe VIE, Nnabuenyi HO (2013) Physicochemical Studies of Water from Selected Boreholes in Umuahia North Local Government Area, in Abia State, Nigeria. Int J Pure App Biosci 1: 34-44.

15. Obot EE, Edi DB (2012) Spatial Variation of Borehole Water Quality with Depth In Uyo Municipality, Nigeria. International Journal of Environmental Science, Management and Engineering Research 1: 1-9.

16. El-Taweel GE, Shaban AM (2001) Microbiological quality of drinking water at eight water treatment plants. International Journal of Environmental Health Research 11: 285-290.

17. Ferguson AS, Layton AC, Mailloux BJ, Culligan PJ, Williams DE, et al. (2012) Comparison of fecal indicators with pathogenic bacteria and rotavirus in groundwater. Science of The Total Environment 431: 314-322.

18. Mackintosh G, Colvin C (2003) Failure of rural schemes in South Africa to provide potable water. Environmental Geology 44: 101-105.

19. Banjo AD, Lawal OA, Adeduji OO (2005) Bacteria and fungi isolated from housefly (Musca domestica L.) larvae. Afr J Biotechnol 4: 780-784.

20. Birkmann J (2007) Risk and vulnerability indicators at different scales: Applicability, usefulness, and Policy Implication. Environmental Hazards 7: 20-31.

21. Yusuf AA, Francisco H (2009) Economy and Environment Program for Southeast Asia. Economy and Environment Program for Southeast Asia, Singapore.

22. Pru"ss-U“" stu"n A, Bos R, Gore F, Bartram J (2008) Safer water, better health: Costs, benefits and sustainability of interventions to protect and promote health. Geneva: World Health Organization.
23. Uwakwe FE, Iwuala MOE (2012) Studies on the Characteristics and Public Health Implications of Waste Dumpsites in Owerri, Imo State, Nigeria. International Journal for Environmental Health an.

24. American Public Health Association (APHA) (1998) Standard Methods for the Examination of Water and Wastewater. American Public Health Association, Washington, D.C.

25. IPCC (2012) Summary for Policymakers. In: Field CB, Barros V, Stocker TF, Qin D, Dokken DJ, et al. Managing the Risks of Extreme Events and Disasters to Advance Climate Change Adaptation: A Special Report of Working Groups I and II of the Intergovernmental Panel on Climate Change. Cambridge: Cambridge University Press. pp. 1 -19.

26. Adger WN (2006) Vulnerability. Glob Environ Change 16: 268-281.

27. Brooks N, Adger WN, Kelly PM (2005) The Determinants of Vulnerability and Adaptive Capacity at the National Level and the Implications for Adaptation. Glob Environ Change 15: 151-163.

28. Dickin SK, Schuster-Wallace CJ, Elliott SJ (2013) Developing a Vulnerability Mapping Methodology: Applying the Water-Associated Disease Index to Dengue in Malaysia. PLoS ONE 8: 63584.

29. Ubuoh EA (2012) Harvested Rainwater Quality in Parts of Oil Producing Areas of Akwa Ibom State, Nigeria. PhD thesis submitted to Post Graduate Studies, University of Nigeria, Nsukk pp. 1-316.

30. Idika N, Odugbemi TO, Ekanem EE (2005) An evaluation of bacteriological quality of water consumed by inhabitants of some rural areas of Lagos State, Nigeria. J Health Biomed Sci 4: 61-66.

31. Opara AU, Nnodim J, Okorochi E, Nwanjo HU (2011) Microbialand physico-chemical qualities ofwater sources in a pig-rearing rural community, south eastern Nigeria. International Science Research Journal 3: 25-28.

32. Water Stewardship Information Series (2007) Total, Faecal and E. coli bacteria in ground water.

33. Boyer DG, Neel JPS (2010) Nitrate and fecal coliform concentration differences at the soil/bedrock interface in Appalachian silvopasture, pasture, and forest. Agroforest Systems 79: 89-96.

34. Schijven JF, Hassanizadeh SM, Husman AMD (2010) Vulnerability of unconfined aquifers to virus contamination. Water Research 44: 1170-1181.

35. Owuama CO, Uzoije AP (2004) Waste disposal and groundwater quality in Owerri, Nigeria. J Environ Syst 31: 69-79.

36. Hambsch B, Bockle K, Lieverloo JHM (2007) Incidence of faecal contaminations in chlorinated and non-chlorinated distribution systems of neighbouring European countries. Journal of Water and Health 5: 119-130.

37. Duru CN, Okechi RN, Ukagwu N, Ibe IJ, Ahumibe NC (2012) Bacteriological Quality of Municipal Borehole waters in Imo State, Nigeria. Journal of Biodiversity and Environmental Sciences 2: 18-22.

38. Okechi RN, Onyekere JA, Azuwike CO, Nnokwe JC, Ibe IJ et al. (2013) Groundwater Quality of Boreholes located Around Cassava Processing Mills. Journal of Research in Public Health 2: 056-062.

39. Butler D, Ward S, Sweetapple C, Astaraie-Imani M, Diao K, et al. (2016) Reliable, resilient and sustainable water management: the Safe \& SuRe approach Global Challenges 1: 63-77.

40. Fleisher JM, Kay D, Wyer MD, Godfree AF (1998) Estimates of the severity of illnesses associated with bathing in marine recreational waters contaminated with domestic sewage. International Journal of Epidemiology 27: 722-726.

41. Teunis PFM, Nagelkerke NJD, Haas CN (1999) Dose Response Models for Infectious Gastroenteritis. Risk Analysis 19: 1251-1260.

42. UN-Water (2010) Climate change adaptation: the pivotal role of water.

43. Marlow DR, Moglia M, Cook S, Beale DJ (2013) Towards sustainable urban water management: a critical reassessment. Water Res 47: 7150-7161.

44. Labaka L, Hernantes J, Sarriegi J (2016) A holistic framework for building critical infrastructure resilience. Technological Forecasting and Social Change 103: 21-33. 
Citation: Attah UE (2017) The Vulnerability of Underground Water Resources to Bacteriological Indicators in Parts of Owerri West of Southeastern Nigeria. J Environ Anal Chem 4: 215. doi:10.4172/2380-2391.1000215

Page 7 of 7

45. Njoku JD, Aniekan IS, Ebe TFI, Wuji MC (2009) Comparative quality assessment of Rural water sources in Nkek Community in Ukanafun L.G.A. of Akwa Ibom State in Rural Water Supply in Nigeria. In: Uzo M,
Ijioma IMA, Onyenechere EC (eds.), published by in Nig. By Cape Publishers Int'l Ltd, Owerri, Imo State pp. 130-135. 